\title{
Performance Management System in Mozambican Universities: A Literature Review of Theories, Origin and Evolution
}

\author{
Carlos Bire Caixote ${ }^{1}$, Bashi Mothusi ${ }^{1} \&$ Thekiso Molokwane ${ }^{1}$ \\ ${ }^{1}$ Department of Political and Administrative Studies, University of Botswana, Botswana \\ Correspondence: Thekiso Molokwane, Senior Lecturer, Department of Political and Administrative Studies, \\ University of Botswana, Botswana.
}

Received: September 25, 2020

Accepted: October 24, 2020

Online Published: November 11, 2020

doi:10.5430/ijba.v11n6p52

URL: https://doi.org/10.5430/ijba.v11n6p52

\begin{abstract}
From the end of the 1970s up to the 2000s, governments in the developed and developing countries were involved in implementing economic, social, political, cultural and legal reform programs. The first wave of public sector reforms came under the Structural Adjustment Programs (SAPs) which were implemented in most of the developing countries from the late 1970s to the early 1990s. The second wave, which started in the early 1990s, was propelled by influence generated by proponents of the New Public Management (NPM) school of thought. The major objective of reforms was to enhance performance and productivity in public sector organizations including higher education institutions. This practice was grounded on certain theories and models, mainly public-choice theory and goal-setting theory under the New Public Management (NPM) model. The Government of Mozambique has adopted a performance-based approach to implementing public sector reforms. This study, which employs a qualitative literature survey with secondary data as its primary research source, discusses and analyzes literature on the design and implementation of a Performance Management System (PMS) in the public sector including public universities of Mozambique. The study also discusses the origins and evolution of the theories which are linked to PMS and their applicability to the public universities of Mozambique as they started embracing PMS as a tool for improving performance of individuals and the organization as a whole.
\end{abstract}

Keywords: performance management system, Mozambique, new public management, public sector, higher education sub-sector, public universities

\section{Introduction}

The adoption and implementation of the New Public Management (NPM) model, which gained momentum in the early 1990s worldwide, placed the Mozambican Public Administration and Management System under the spotlight raising a number of challenges. Public sector reforms literature on Mozambique indicates that the implementation of the reforms brought in its trail, considerable gaps between reform public policies and implementation competences as well as requisite expertise or skills needed to execute the reforms effectively (Molefhe, 2011; Awortwi, 2010; Alar, 2010; Monteiro, 2016).

The Government of Mozambique faces five main challenges of effectively implementing the public sector reforms. These are: professionalization of human resources through training and development programmes; steering performance of civil servants including academic staff in higher education sub-sector; improving productivity using Performance Management System (PMS) in public sector organizations; investing in human capital development for reforming and developing public sector and; expanding the role of the country's private sector through contracting out, privatization and other forms of Public-Private Partnership (PPP) strategies and policies (World Bank Group, 2014, p.8). These have placed enormous pressure on the government to regulate multiple actors operating in the public sector (Government of Mozambique, 2012; World Bank Group, 2014).

To understand how key government higher education officials, university leaders and academic staff members are responding to the government's challenges of public sector reforms especially the design and implementation of a PMS under the NPM model, this article sets out to undertake four main objectives. First is to review literature on the design and implementation of PMS in Mozambique and secondly, to discuss public sector reforms within the context of the NPM model in the developed and developing countries including in Mozambique. The third objective is to briefly explain the origins and evolution of PMS in Mozambique's public sector, including public universities and 
lastly, to explore the linkage or connection between three theories namely goal-setting, public choice and expectancy as well as the design and adoption of PMS in public universities in Mozambique.

\section{A Review of Performance Management System Literature}

Literature illustrates that the design and implementation of PMS in different organizations from the developed and developing countries has been studied. This includes in particular, the impact of PMS on staff motivation, job satisfaction and organizational effectiveness in public and private sectors, including universities (Molefhe, 2011; African Development Bank Group, 2017). When discussing a roadmap for developing, implementing and evaluating PMS in the United States of America, it is stated that PMS needs to be aligned with organizational goals and objectives as well as support the organization's direction (i.e. vision, mission, values and principles of core business) (Pulakos, 2004). In other words, PMS must be viewed as a tool that can be used to improve the performance of individuals which will ultimately facilitate the pursuance and attainment of organizational goals. If PMS is well-developed and efficiently implemented, performance tools and processes are needed to make the system user-friendly and well-accepted by the- organization's staff being managers and their subordinates (Dorse and Mueller-Hanson, 2017; Pulakos, 2004, p.45). Managers and their subordinates must use PMS in a manner that brings visible, value-added benefits in the areas of staff performance planning, training and development, feedback, review meetings and achieving expected results effectively (Pulakos, 2004, p.45).

Any discussion of the reform of higher education management and governance at the institutional and system level must be set within the broader context of the NPM model. This is mainly because universities are large, complex organizations that perform a significant role in the social, economic, political and cultural life of the societies and contexts in which they are located and operating. To varying degrees, policy makers have championed the broad and underlying relevance of commercial corporate governance reform to the public and not-for-profit sectors. In the same vein, they contend that the politicians believe that public sector governance reform rests on the belief that the fundamental principles underpinning commercial sector corporate governance reform such as transparency, rebalancing stakeholder and executive powers, effective reporting and accountability, are as relevant to health services, public schools, the charitable sector and universities as they are to private corporations (Mazza, Quattronne and Riccabonni, 2008, p.205-207).

Further to the foregoing, Mazza et al. (2008) observe that a future higher education system which is characterized by large increases in teacher-student ratios, and diversion of resources away from teaching as well as research, tends to undermine learning and education development, academic staff performance improvement and achievement of the desired teaching and research quality standards within universities. They also state that the universities will continue to be globally competitive for the next decades both in the developed and developing countries as they implement PMS for academic staff members with a view to improving their level of productivity. Further to this, the authors indicate that the budgetary processes that encourage internal competition between disciplines and funding policies that create quasi-competition between universities, ultimately undermines the overall global competitiveness of the higher education sub-sector. Hence, it is of paramount importance that accountability for performance and more efficient administration should be viewed as a suggestion for further managerialism, performance measurement and decreased involvement of academics in institutional operations.

Finally, they warn that there are some consequences for increasing academic staff workloads more especially if they are accompanied by weak performance measurement practices and unavailability of reward structures or incentives schemes. Clearly, the financing of higher education sub-system over the past decades, with tied grants and performance-based funding in specific areas, such as research development and qualified human capital or talent retention and training for performance improvement will continue for the next decades (Mazza, et. al., 2008). Armstrong and Taylor (2014) also make pertinent observations in terms of what needs to be done when PMS is introduced. They state that overall performance assessment should be based on a general analysis of performance under the headings of the performance agreement about future action rather than to produce summarized and potentially superficial judgement. They also state that the assessment should identify high-flyers and those who are failing to meet acceptable standards. This will assist the Managers and the employees to have a constructive dialogue and agreement in terms of what can be done to assist the poor performers (Armstrong and Taylor, 2014, p.339-340). This should be done within the framework set by the legal performance management guidelines, organizational procedures, rules, regulations and laws that should govern the whole PMS implementation process in an organization.

Notwithstanding the financial support that is given to public universities by the central government, it is not in dispute that the allocated funds do not meet the needs, demands and expectations of the staff members. When 
assessing the conditions of decreased availability of resources for higher education to develop teaching-learning process in a manageable manner and to achieve desirable research outcomes, Turk (2016) states that the budgets of universities are under strain and therefore, need to improve the usage of scarce resources allocated by the government. The universities are expected to take the necessary steps to improve the effectiveness of management as well as adopt modern PMS professional practices. There is need for an extensive use of performance assessment instruments combined with Pay-For-Performance (PFP) model that will promote motivation of academic staff. However, it must be noted that the combination of the two variables (i.e. staff performance measurement and pay-for- performance) can also create excessive competition that may in turn result in reduced cooperation among the academic staff members within the same university.

The introduction of qualitative aspects of appraisal needs to be implemented and combined with quantitative aspects of performance assessment that takes into account the academic staff job descriptions. Thus, it would be necessary to develop long-term goals and setting such goals would allow the academic staff to focus their activities on improving the quality of teaching and research, based on the university's Mission. Additionally, such goals must be aligned to the PMS objectives. Performance assessment should not be restricted to the teaching and research fields. Rather, it should also be done to align the various tools and instruments such as Human Resource succession plans, training and development plans, personal development plans and others with the overarching goals of PMS (Turk, 2016). Further to the foregoing discussion, Aguinis (2016) argues that organizational Managers must possess knowledge and skills to manage performance of their subordinates effectively. Managers as coaches should give positive and negative feedback as well as conduct performance review meetings on the basis of mutual trust, mutual respect and fairness. The coaching role should be an on-going process in which the Managers direct, motivate, recognize and reward high performance work ethics and behaviour displayed by their subordinates.

Maimela and Samuel (2016) are of the view that the implementation of PMS in higher education institutions is not entirely undesirable if the system is properly designed and effectively managed. It is imperative to adopt a participative approach in the design, administration and management of the system to ensure validity, trust, fairness, transparency and credibility or acceptance by employees of an organization.

\section{The Three PMS Theories}

The review of literature on PMS reveals three dominant theories and two models that are usually used for its planning, designing and implementation in public organizations including universities. These theories are goal-setting; public-choice; and expectancy. The two models are Balanced Scorecard (BSC) and, 360 Degree Feedback (360-DFB). This study focuses only on the three theories mentioned above that constitute the foundations of the design and implementation of PMS in Mozambican universities. The available literature indicates that the goal-setting theory helps the organizational Managers to set up goals and objectives by involving and engaging staff members at the design and implementation stages of PMS (Bhattacharya, 2018, p.2). Staff participation in goal setting process is more acceptable and effective in small companies, while it is not always desirable in large organizations because such participation can lead to conflicts with the management's long-term goals.

In large organizations, the goal setting process is feasible in the long-term and requires much more resources. In small organizations, this process is more feasible in the short-term and it increases staff involvement and engagement in goals attainment with limited resources (Chetty, 2019, p.3). Therefore, the goal-setting theory is much more applicable and acceptable in smaller organizations with limited resources and less conflicts with management for the attainment of long-term organizational goals.

The public-choice theory is related to public interests and it helps the Managers to aggregate individual economic interests (i.e. pay for-performance), welfare (including non-monetary incentives for performance or fringe benefits) and social choice to perform towards attainment of organizational goals (Werner, Schuler and Jackson, 2012, p.286). Although this theory has its roots in the field of Economics and uses a mathematical approach to aggregate individual interests in modern organizations, it was later applied in Political Science for studies focusing on the bureaucracy, democracy, constitutional and electoral processes and others. In Political Science, public-choice theory is often used to explain how political decision-making process results in desirable outcomes for the politicians that are in some cases in conflict with the preferences of the general public interests and/or choices (Schneider, 2014, p.4). Just like in Political Science, the public-choice theory is also being applied in the field of Public Administration and can be viewed as influencing the goal-setting process by taking into account the organization's core business and aligning it with the public interests and/or choices.

The expectancy theory has to do with meeting both the organizational and individual employees' expectations through performance-to-outcomes expectancy, perceived effort-reward expectancy probability and an effective PMS 
(Chetty, 2019, p.3). Expectancy theory is applied practically in almost all types of organizations. This theory is primarily used in all aspects of labour relationship with the main focus being on monitoring and reviewing staff performance, recruitment and selection process, outcome of organizational training assessment analysis and performance improvement analysis towards the attainment of the organization's goals and objectives. The expectancy theory is also applied to identify variables that motivate individual staff performance improvement and productivity at workplace. It has to do with ensuring staff involvement and engagement towards the achievement of goals and objectives, while the public-choice theory has to do with using economic and social strategies to guarantee performance and productivity improvement (Werner, Schuler and Jackson, 2012, p.287). And the expectancy theory has to do with using motivation variables and strategies for boosting high staff performance at the workplace.

\section{The Origins and Adoption of PMS in Mozambique}

This sub-section discusses a brief historical background and experience of designing and implementing PMS models in the public sector and higher education sub-sector since Mozambique became independent in 1975 to date. From the very early stages of independence, the Mozambique Liberation Front (MLF or FRELIMO) made it a point to appraise performance of its soldiers and party members in various military, political, economic, social and cultural realms (FRELIMO, 1978, p.3). In 1977, the nationalist government approved a new Constitution based on the political and economic socialist system. And in 1978, FRELIMO's Standing Political Committee approved a document which provided the general guidelines for introducing a performance management model in public sector organizations including the party's units (FRELIMO, 1978; Funada-Clessen, 2012). The model was called the "Socialist Award for Comrades' Performance Appraisal" (SACPA) and its main purpose was to measure performance, give awards to high-performers and set disciplinary measures for low performers.

The government adopted such a performance measurement practice for organizations and staff based on what was learned from countries such as the former Soviet Union States, Eastern Germany, Algeria and Tanzania. These countries supported FRELIMO in ideological, military and financial terms during the liberation struggle to attain national independence (Funada-Clessen, 2012; Monteiro, 2016).

The socialist award for comrades' performance appraisal model gained a relevant historical meaning for new Public Administration. The aim was to measure performance of civil servants only with minor changes made to SACPA's indicators and parameters in 1997 with a view to adjusting it to the country's new economic and social context (Monteiro, 2016). This new model was called "Annual Performance Appraisal Form" (APAF) or "Staff Performance Appraisal Service Form - SPASF" (World Bank, 1997; Funada-Clessen, 2012; and Monteiro, 2016). The purpose of the new instrument was to introduce permanent appraisal practice of assessing individual performance and merit of civil servants in exercising their duties and responsibilities.

Mouzinho, Fry, Levey and Chilundo (2003) indicate that the major challenge which was faced by the Mozambican public sector at independence was huge shortage of qualified public sector employees including academic staff in universities. This was due to two factors, which are, the exodus of the Portuguese staff working in government institutions and lack of investment for training higher education national academic staff to cover the shortage faced by the Government of Mozambique. Sorting out these two human resource problems, the university management adopted both short-term and long-term measures for recruiting qualified teachers and technicians from other countries around the world.

The higher education sector reforms were designed for academic staff and were drafted firstly by Eduardo Mondlane University (EMU) as the oldest and biggest university of the country in 1997 (Chilundo, 2006, p.9). This initiative resulted in approval and implementation of the first formal University's Five Year Strategic Plan (1999-2003) which was supported financially by the World Bank (World Bank, 2004). Mozambique's higher education reforming initiative was linked to a triangular approach to PMS using profiling, contracting out and use of individual portfolios (Santos and Salvucci, 2016, p.2-5). The first initiatives of designing and implementing human resources performance management systems and/or models came from private companies that had growth and expansion of their business as their companies' strategies (Osborne and Gaebler, 1993, p.13-21; and Ayee, 2000, p.5). The HR professional practice of measuring individual performance in private organizations was followed by performance management in modern public sector organizations, both from developed and developing countries.

Later on, the human resources performance appraisal practice was introduced in government's institutions aimed at generating additional income, to cover financial expenses incurred during the implementation of activities in various sectors of the economy (Monteiro, 2016, p.43). The affected sectors were, among others, health, education, defence, public security and safety, sanitation and potable water supply in urban and sub-urban areas of metropolitan cities, small cities and villages (Osborne and Gaebler, 1993; Mwita, 2000). In 2004, the government established a new 
ministry responsible for managing tertiary institutions called Ministry of Science, Technology and Higher Education (MSTHE) (Chilundo, 2006, p.8). In the same year, the government approved specific PMS guidelines for academic and research staff working in Higher Education Organizations (HEOs). And in 2005, Eduardo Mondlane University (EMU) implemented, for the first time in the history of the country, a PMS for academic staff members. In 2006, the above-mentioned ministry approved specific PMS guidelines for academic staff working in tertiary institutions (Chilundo, 2006; Government of Mozambique, 2009; Awortwi, 2010; and Monteiro, 2016).

This development led to three other universities following in the footsteps of EMU as they embraced PMS. These universities are the private Catholic University of Mozambique which embraced PMS in 2007; followed by Maputo Pedagogical University in 2012 and Lurio University in 2014. All these reforming initiatives were implemented under the NPM model adopted in the country which is based on the strong belief that public and private organizations can be managed in the same manner as the line separating the two sectors is blurred (Mouzinho, et al. 2003; World Bank Group, 2004; Chilundo, 2006; UEM, 2010; Government of Mozambique, 2014; and OECD, 2014).

In 2009, the government reviewed and approved a new PMS for civil servants and it was implemented in 2010. The system, which was called "Performance Management System for Public Administration" (PMSPA), was implemented under the new reform program called "Public Administration Reform and Development Strategy 2012-2025" (PARDS).The objectives of PARDS are, among others, to consolidate public sector reforms results achieved earlier by the first global reform strategy; to strengthen meritocracy of civil servants through PMS implementation; to recognize high-performance and discourage low-performers; and to motivate public servants (Government of Mozambican, 2014; African Development Group, 2017). As with every public sector of developing countries, the Mozambican public sector organizations including universities were also targeted by the NPM reform programs implemented in the country.

The major signs of the NPM reforms in the country's tertiary landscape are the expansion of institutions; increase of academic programmes, students' intake and graduation rates in number and quality; introduction of private universities and colleges as new actors providing tertiary education; reform of academic curriculum adjusted to the public sector reform demands; the design and implementation of PMS for measuring academic and research staff members' performance; university budget allocation and emphasis on the existence of financial accountability mechanisms along with managerial methods to improve organizational performance. It also focused on academic staff performance and productivity improvement, teaching-learning quality assurance and on research outcome increase, which appeared to be the key concern together with human capital development in reforming the higher education subsector in Mozambique.

\section{Analysis and Discussion}

The universities, like in many other private sector organizations, are the backbone of success of PMS (Bogt and Scapens, 2012). However, most of the literature on PMS does not give adequate attention to performance management and assessment of academic staff of universities (Tolofari, 2005). The literature focuses mainly on the adoption of PMS to various sectors of the economy and does not pay much attention to universities. Furthermore, previous research results of PMS literature have not shown a significant positive impact of human capital development on the performance of knowledge production-oriented universities in the developing countries (Tolofari, 2005; Bogt and Scapens, 2012; and Mazibuko, 2017). Despite widespread recognition of human capital development for universities' competitiveness and academic staff performance, there is little research conducted on the design and implementation of PMS for academic staff members in Mozambique. In the same vein, there is lack of specific literature on human capital development based on knowledge production, dissemination of research findings and knowledge export-oriented universities in Mozambique.

Human capital development practices in a country's higher education are considered as the primary source by which knowledge production, dissemination of research findings and knowledge export-oriented universities can develop and nurture the skills and abilities of academic staff. This also includes technical and administrative staffs that are expected to achieve innovative high-performance levels and competitiveness within universities. Thus, universities need to adopt those HR management practices that develop their employees' capacity to compete in higher education international markets through innovative technologies and products by formulating and implementing PMS that is result-oriented or output-based. The PMS aspects mentioned above are not sufficiently explored in most Human Resource Management literature in Mozambican universities. This constitutes one of the major gaps in literature in so far as performance management in universities is concerned. The main reason why most of the reforms implemented in the mid-1990s in Mozambique always failed to achieve their expected objectives is because the 
majority of the country's university managers do not take into consideration the academic staff as a competitive human capital development factor for effective operation of the universities (Awortwi, 2010; Massingue, 2013; and OECD, 2014).

The majority of the public universities in Mozambique that are currently implementing academic reforms do not consider the important aspects of human capital development. Issues of PMS for academic staff based on knowledge production, dissemination of research findings and university export-oriented principles, human capital development and promotion of high performance culture are neglected. The review also reveals that despite the widespread recognition of human capital development for universities' competitiveness and staff performance improvement, there is little research studies on the planning, design and implementation of PMS in Mozambican universities. In addition, there is little discussion about the nature of academic and research staff performance information and reward systems that can be used to retain talented human capital working for the universities (Open Society Foundations, 2012; Mouzinho, et al. 2003).

Mwita (2000) argues that some studies have indicated that the traditional Performance Appraisal Systems (PAS) inhibited the creativity of both academic and research staff in universities operating in Africa. At the same time, PMS implemented in universities had increased the authority and power of non-academic staff in decision-making process and decreased the voice and freedom of academic staff, due to the bureaucratic power gained by some universities administrative, technical and support staff members combined with politicians' interference in managing universities (Mwita, 2000). This is compounded by the existence of poor reward system which is attributed to the weakness in universities' financial management systems, heavy financial dependence on the government and lack of a systematic and coherent process that can build the capacity of Managers and academic leaders.

Lastly, when it comes to applicability of the three PMS theories to Mozambican universities, the available literature does not clearly indicate if they influenced the decision makers to adopt the tool or system as it currently exists. It is not evident that the setting of organizational goals was done as recommended by the proponents of the goal-setting theory. In the same token, it is difficult to ascertain that the underpinnings of the public-choice theory were considered when the performance management reforms were introduced in public universities. Similarly, there is nothing in the literature that suggests that the expectancy theory was used.

\section{Conclusion}

This paper presented a review of the literature on PMS in Mozambique's public universities. The review illustrated the significance of assessment of staff performance and the risks of having it become a pervasive feature of modern organizations. It is evident from the paper that several challenges were encountered in the implementation of PMS. These include lack of clear academic job descriptions, poor verification of performance measures, limited transparency, limited consultation of academic staff members and others.

It is also clear from the paper that public universities in Mozambique which have already embraced PMS and those which are likely to follow suit, need to adopt those Human Resource management practices which are geared towards developing their employees' capacity to compete in higher education international markets. This calls for the adoption of a performance management system which is result-oriented or output-based.

Since some of the critical aspects of PMS have not been sufficiently explored in most Human Resource Management literature in Mozambican universities, this constitutes a major gap in literature. This is compounded by the fact that little research has been done on the planning, design and implementation of PMS in Mozambican universities as well as the nature of academic and research staff performance information and reward systems that can be used to retain talented human capital working for the universities. These gaps can be filled in by appropriate studies in the future which will assist to present a holistic picture of the performance improvement reform programs in Mozambican universities.

\section{References}

African Development Bank Group. (2017). Annual Report on African Education Development Research 2017. Economic and Education Development Research Working Paper Series.

Agarwal, A. (2011). Models and Theories of Performance Management System. Project Guru, University Press, Delhi University, New Delhi. Retrieved May 17, 2020, from http://www.differencebetween.net/language/words-language/difference-between-hcm-and-hrms/\#ixzz1VK 6OLOth

Aguinis, H. (2016). Performance Management (3rd ed.). Pearson Education Limited, London, England. 
Alar, F. I. (2010). Performance Management of the Police in the Context of Public Sector Reform in Mozambique. PhD Thesis, Erasmus University, Rotterdam.

Armstrong, M. (2011). Handbook of Strategic Human Resource Management (11th ed.). Kogan Page Limited, London.

Armstrong, M., \& Taylor, S. (2014). Armstrong's Handbook of Human Resource Management Practice (13th ed.). Kogan Page, Ashford Colour Press Ltd, London.

Awortwi, N. (2010). Building New Competencies for Government Administrators and Managers in an Era of Public Sector Reforms: The Case of Mozambique. International Institute of Social Studies, Erasmus University, The Hague, The Netherlands. https://doi.org/10.1177/0020852310381803

Ayee, J. R. A. (2005). Public Sector Management in Africa. African Development Bank (AfriDB). Economic Research Working Paper Series $N^{o} 82$ (November 2005). University of Ghana; Legon, Ghana. Retrieved from http://www.afdb.org

Bhattacharya, A. (2018). Expectancy Theory of Performance Management System. Project Guru, University Press, Delhi University, New Delhi. Retrieved May 17, 2020, from http://www.differencebetween.net/language/words-language/difference-between-hcm-and-hrms/\#ixzz1VK6OL0th

Bogt, H., \& Scapens, R. M. (2012). Performance Management in Universities: Effects of the Transition to More Quantitative Measurement Systems. Europe Accounting Review, 21(3), 451-497.

Boselie, P. (2010). Strategic Human Resource Management: A Balanced Approach (2nd ed.). The McGraw-Hill Education Companies, Berkshire.

Brumbach, P. (2017). The Performance Management, Reward and Productivity (8th ed.). New York University, New York, US.

Cepiku, D., \& Mititelu, C. (2020). Public Administration Reforms in Albania and Romania: Between the Weberian Model and the New Public Management. Workshop on "Public Administration in the Balkans - from Weberian Bureaucracy to New Public Management". South Eastern European developments on the administrative convergence and enlargement of the European Administrative Space in Balkan states 5-6 February, Athens, Greece.

Chetty, P. (2012). Theory and Practice of Performance Management System. Project Guru, University Press. Delhi University, New Delhi. Retrieved May 17, 2020, from http://www.differencebetween.net/language/words-language/difference-between-hcm-and-hrms/\#ixzz1VK 6OL0th

Chetty, P. (2019). Goal-Setting Theory and Performance Management System. Project Guru, University Press. Delhi University, New Delhi. Retrieved May 17, 2020, from http://www.differencebetween.net/language/words-language/difference-between-hcm-and-hrms/\#ixzz1VK6OL0th

Chilundo, A. (2006). Capacity Building in Higher Education in Mozambique and the Role Played by Co-operating Foreign Agencies: The Case of the World Bank. A Paper Commissioned by the Regional Scientific Committee for Africa. Accra, Ghana.

Commonwealth Secretariat. (1992). Review of the Eduardo Mondlane University Governance, Planning, Performance and Management Report: Present and Future. University Press, Eduardo Mondlane University, Maputo, Mozambique.

Cunningham, J. B. (2016). Strategic Human Resource Management in the Public Arena: A Managerial Perspective. Palgrave, Macmillan Education, London, UK. https://doi.org/10.1007/978-1-137-43241-4

Dauda, Y. (2018). A Review of Performance Appraisal Systems in Different Countries: The UK, India, South Africa and Ghana. Retrieved from http://www.ripublication.com

Dessler, G. (2011). Human Resource Management (12th ed.). Pearson Education Limited, Edinburg, England.

Dorse, D., \& Mueller-Hanson, R. (2017). Performance Management That Makes a Difference: An Evidence-Based Approach. Society for Human Resource Management, Science to Practice Series, USA.

Duarte, S., \& Bastos, J. (2016). Trajectory and Challenges of Academic Staff Performance Assessment: The Case of Pedagogical University of Mozambique. Revista Transmutare (RTr), 1(1), 22-37. https://doi.org/10.3895/rtr.v1n1.3891 
Frelimo. (1978). Anti-Colonial Political Organizations: The Socialist Award Performance Appraisal Model Implementation in Mozambique. Mozambique Liberation Front - Frelimo. The African Revolution Voice Newspaper No.57. Melville J. Herskovits Library of African Studies, North-western University Libraries, Store Collections. London, UK.

Funada-Clessen, S. (2012). The Origins of War in Mozambique: A History of Unit and Division. African Minds, African Books Collective, Compress.dsl, Capitili Printing, Johannesburg, SA.

Ghana, T. (2018). A Review of Performance Appraisal Systems in Different Countries: The UK, India, South Africa and Ghana. International Journal of Applied Environmental Sciences, 13(2), 203-221.

Gichuki, B. W. (2014). Influence of Performance Management on Employee Productivity in the Civil Service: A Case of the Immigration Department in Kenya. University of Nairobi.

Government of Mozambique. (2009). Performance Management System for Public Administration-SIGEDAP. Ministry of Public Service, Decree 55/2009, the Council of Ministers, National Press, Maputo, Mozambique.

Government of Mozambique. (2012). Final Evaluation Report on Global Strategy for Public Sector Reform 2001-2011 Implementation Process in Mozambique. Ministry of Public Service, CIRESP Part I and II, National Press; Maputo, Mozambique.

Government of Mozambique. (2014). Review Report of Ten-Year Rolling Strategic Plan for Higher Education 2010-2020 Implementation in Mozambique. The Ministry of Science, Technology and Higher Education, National Press; Maputo, Mozambique.

Kenya, Government of Mozambique. (2015). Human Resource Management Annual Report for Public Sector's Performance Assessment. Ministry of Public Service, National Press, Maputo, Mozambique.

Levieque, A. (2013). 4Ps de Avaliação de Desempenho Humano na Empresa (4Ps of Human Performance Evaluation in a Company). Editora Publifix Limited, Maputo.

Maimela, E. M., \& Samuel, M. O. (2016). Perception of Performance Management System by Academic Staff in an Open Distance Learning Higher Education Environment. SA Journal of Human Resource Management/SA Tydskrif vir Menslikehulpbronbestuur, 14(1), a784. https://doi.org/10.4102/sajhrm.v14i1.784

Massingue, O. J. (2013). Impacto do SIGEDAP na Qualidade dos Serviços Públicos: Uma Análise da sua Implementação no Balcão de Atendimento Único da Cidade de Maputo 2010-2013 (The SIGEDAP Impact on Public Servisse Delivery Quality: The Implementation Analysis on the One-Shop Stop in Maputo City Council 2010-2013). University Press, Universidade Eduardo Mondlane (UEM); Maputo.

Mazibuko, L. T. (2017). Academic Staff Perceptions of Performance Management: A Qualitative Study. School of Applied Human Sciences, University of Kwazulu Natal (UKZN), KwaZulu Natal, SA.

Mazza, C., Quattronne, P., \& Riccabonni, A. (2008). European Universities in Transition: Issues, Models and Cases. Edward Elgar Publishing Limited, Inc. Cheltenham, UK.

Molefhe, K. (2011). Understanding Adoption, Implementation and Outcomes of New Public Management Reforms in Developing Countries: A Case Study of Botswana. Faculty of Business and Law, University of Newcastle, Australia.

Monteiro, J. O. (2016). Governance and Decentralization in Mozambique Post-War Period. In M. Roy, \& F. Oliver (Eds.), Ending Africa's Wars: Progressing to Peace. James Currey Limited, First African World Press, Oxford, UK.

Mouzinho, M., Fry, P., Levey, L., \& Chilundo, A. (2003). Higher Education in Mozambique: A Case Study. University Press, Eduardo Mondlane University and James Currey, Oxford University, Oxford, UK.

Murphy, J. (2014). Managing Professional Development of Academic Staff to Enhance University Performance. PhD Thesis, School of Management, University of Bath, Bath, UK.

Mwita, J. I. (2000). Performance Management Model: A Systems-Based Approach to Public Service Quality. International Journal of Public Sector Management, 13(1), 14-17. https://doi.org/10.1108/09513550010334461

Neuman, W. L. (2014). Social Research Methods: Qualitative and Quantitative Approaches (7th ed.). Pearson Education Publication Limited, London, England.

No 91. (2017). Abidjan, Cotê d'Ivoire. 
OECD. (2014). Public Management Reform and Economic Development in Developing Countries. OECD, Paris, France.

Open Society Foundations. (2012). Mozambique Effective Delivery of Public Services in the Education Sector. AfriMap, Open Society Initiative for Southern Africa (OSISA), Wits, Compress dsl.com, Johannesburg, SA.

Osborne, D., \& Gaebler, T. (1993). Re-inventing Government: How the Entrepreneurial Spirit is Transforming the Public Sector. Penguin, New York, US.

Pulakos, E. D. (2004). Performance Management: A Roadmap for Developing, Implementing and Evaluating Performance Management Systems. Society for Human Resource Management Foundation 45-49, Alexandria, US.

Rowley, J., \& Slack, F. (2004). Conducting a Literature Review. Management Research News, $27(6), 32$. https://doi.org/10.1108/01409170410784185

Santos, R., \& Salvucci, V. (2016). Poverty in Mozambique: Significant Progress but Challenges Remain. Policy Brief Recommendations, University of United Nations. New York. US.

Schneider, F. (2014). Public Choice: An Introduction. Johannes Kepler University, Linz, Belgium. Retrieved from https://w.w.w.researchgate.net.friederich.scheneider/publications

Schuler, W., \& Jackson. (2012). Human Resource Management (11th ed.). International Edition, South-Western SENGAGE-Learning, Canada.

Sutton, A. (2016). Systematic Approaches to a Successful Literature Review. SAGE Publications, Los Angeles, US.

Tolofari, S. (2005). New Public Management and Education. Policy Futures in Education, 3(1), 75-89.

Turk, K. (2016). Performance management of academic staff and its effectiveness to teaching and research - Based on the example of Estonian universities. Trames Journal of the Humanities and Social Sciences, 20(1), 1-20.

Turk, K., \& Killumets, E. (2016). Performance Management of Academic Staff on the Example of the Faculties of Economics in University of Tartu and in Tallinn University of Technology. The University of Tartu.

Turner, J. R., Baker, R., \& Kellner, F. (2018). Theoretical Literature Review: Tracing the Life Cycle of a Theory and its Verified and Falsified. Human Resource Development Review, 17(1), 34-61. https://doi.org/10.1177/1534484317749680

UEM. (2010). The Evaluation of the Strategic Plan 1999-2003 and RUMA Project Implementation: UEM Annual Report 1010. Maputo, Mozambique.

World Bank Group. (1997). Education Policy for Sub-Saharan Africa: Adjustments, Revitalization and Expansion. World Bank; New York, US.

World Bank Group. (2004). Public Administration Country Profile: Republic of Mozambique. Division for Public Administration and Development Management (DPADM), Department of Economic and Social Affairs (DESA); United Nations, New York, US.

World Bank Group. (2010). World Bank Development Indicators; World Bank. Washington, DC; US.

World Bank Group. (2014). World Bank Development Indicators; World Bank. Washington, DC; US.

\section{Copyrights}

Copyright for this article is retained by the author(s), with first publication rights granted to the journal.

This is an open-access article distributed under the terms and conditions of the Creative Commons Attribution license (http://creativecommons.org/licenses/by/4.0/). 